\title{
Serum leptin level has a positive correlation with BMI and creatinine clearance in CAPD patients
}

\author{
Seirafian $\mathrm{S}^{1}$, Momeni $\mathrm{A}^{2}$, Taheri $\mathrm{S}^{1}$, Mortazavi $\mathrm{M}^{1}$, Paknahad $\mathrm{Z}^{3}$ \\ Department of Nephrology, Alzahra Hospital, Isfahan University of Medical Science, Isfahan, Iran. \\ seirafian@med.mui.ac.ir
}

\begin{abstract}
Objective: In a cross sectional study, 75 patients (42 males and 33 females) on continuous ambulatory peritoneal dialysis (CAPD) were enrolled from October 2007 to February 2008. Serum levels of leptin, albumin, triglyceride, dialysis adequacy (total KT/V), renal creatinine clearance $(\mathrm{Cr} \mathrm{Cl})$, mid arm circumference and demographic findings were measured in all patients.

Results: The mean age of patients was $53 \pm 14.76$. The history of hemodialysis was seen in 23 patients. Mean serum leptin level in women and men were $27 \pm 23 \mu \mathrm{g} / \mathrm{l}$ and $16 \pm 13 \mu \mathrm{g} / \mathrm{l}$, respectively. A significant correlation of serum leptin level with body mass index (BMI) $(p<0.001)$ and renal $\mathrm{Cr} \mathrm{Cl}(p<0.001)$ was found. There was no significant correlation of serum leptin level with $\mathrm{KT} / \mathrm{V}$, duration of renal failure, serum triglycerides (TG), serum low density lipoprotein (LDL) cholesterol and mid arm circumference $(p>0.05)$.

Conclusions: To our knowledge, this is probably the first study to report that serum leptin level has a direct positive correlation with renal $\mathrm{Cr} C l$ in CAPD patients. This may explain the increase in mortality in patients with lower serum leptin levels (Tab. 2, Fig. 2, Ref. 25). Full Text in PDF www.elis.sk.

Key words: CAPD, leptin, creatinine clearance, KT/V.
\end{abstract}

Leptin is a 16000-Dalton protein that is produced by fat cells; it is secreted into the blood stream, attaches to the leptin binding protein, and reaches the hypothalamus via cerebral spinal fluid (CSF). It decreases the neuropeptid Y, suppresses appetite, and by blocking MSH it decreases hunger which in turn decreases the weight (1). Kidneys play an important role in metabolism and excretion of leptin. Leptin is freely filtered into glomerulus but with very little excretion in urine (2). This is probably because it is reabsorbed and destructed in tubules (3). Serum leptin level is higher in chronic renal failure, hemodialysis and CAPD patients compared to general population $(4,5)$. Some studies reported that the level of leptin in CAPD patients and women is higher compared to hemodialysis patients and men, respectively $(6,7)$ but in other study, serum leptin level has been higher in hemodialysis versus CAPD patients (8). The exact cause of elevated serum leptin level in patients suffering from renal failure is not clear; however some factors including hemodialysis membrane and type of dialysis (hemodialysis versus peritoneal dialysis) (9), low serum erythropoietin level (10), chronic inflammation and hyperinsulinemia (11) may also play a role. Hyperleptinemia has probably a role in

${ }^{1}$ Department of Nephrology, Alzahra Hospital, Isfahan University of Medical Science, Isfahan, Iran, ${ }^{2}$ Division of Nephrology, Department of Internal medicine, Hajar hospital, Shahrekord University of Medical Science, Shahrekord, Iran, and ${ }^{3} \mathrm{Health}$ Faculty, Isfahan University of Medical Science, Isfahan, Iran

Address for correspondence: Momeni Ali, MD, Hajar Hospital, Parastar Avenue, 8816754633-Shahrekord, Iran.

Phone: +09133267459 anorexia and malnutrition of dialysis patients, but there is a controversy in this regard (12-15). To our knowledge there are only a few comprehensive studies on the relation of serum leptin level with nutritional factors. Thus we conducted the present study to find this relation.

\section{Methods and materials}

Patients who had been at least for three months on CAPD program in Al-Zahra university hospital in Isfahan were enrolled in this cross-sectional study after their written and informed consent had been taken. Information was collected from the questionnaire by PD nurse and from patient files covering the period from October 2007 to February 2008. The inclusion criterion was peritoneal dialysis for at least 3 months, and exclusion criteria included patient incompliance, inadequate blood sampling and peritonitis during the study.

The sample volume was calculated by formula:

$\mathbf{n}=\left[\left(\mathrm{z}_{1}+\mathrm{z}_{2}\right)^{2}\left(1-\mathrm{r}^{2}\right) / \mathrm{r}^{2}\right]+2$,

where $\mathbf{n}$ was calculated to equal 63 patients. Of 101 CAPD patients, 75 patients fulfilled the inclusion criteria and entered the study. For sampling, the method of simple random sampling was used. The patients filled in a questionnaire, went through physical and laboratory examinations, and their patient files were examined. Demographic information of patients was obtained from their files. Fasting blood sample was taken at the peritoneal dialysis 
(PD) clinic for measurement of serum leptin (DRG kit, RIA, Germany), cholesterol, triglyceride, LDL, and HDL. Serum, dialysate and urine were analysed for creatinine, serum urea concentration, and albumin (bromo Cresol Green $\{B C G\}$ method). Body mass index $(\mathrm{BMI})$ was calculated by formula $(\mathrm{BMI}=$ weight $\{\mathrm{kg}\} /$ height $^{2}$ (meter $\}$ ), and mid arm circumference was measured by fabric meter. All data collected by PD nurse and data related to calculating the total $\mathrm{KT} / \mathrm{V}$ and renal $\mathrm{Cr} \mathrm{Cl}$ were analyzed by $\mathrm{PD}$ Adequest 2 software, Baxter, USA.

All laboratory tests were taken after 10 hours of fasting and checked in a single laboratory. Separated plasma of patients was kept in -20c environment. After collecting all samples, the variables were measured. T-test and univariate general linear models (GLM) were used to analyze the variables statistically. All data and information are confidential, and for blood sampling an informed consent was taken from every patient.

\section{Results}

In a cross-sectional study carried out in a single center from October 2007 to February 2008, 75 CAPD patients (42 males and 33 females) finished the study.

The mean age of patients was $53 \pm 14.76$ years, (in range of 20-81 years). The most common cause of end-stage renal disease was diabetes mellitus (48 \%) (Tab. 1). The mean age of DM pa-

Tab. 1. Causes of ESRD in patients.

\begin{tabular}{lcc}
\hline Cause & Frequency & Percent \\
\hline Polycystic disease & 1 & 1.3 \\
DM + HTN & 4 & 5.3 \\
DM & 32 & 42.7 \\
Glomerulonephritis & 1 & 1.3 \\
Gout & 1 & 1.3 \\
hypertension & 17 & 22.7 \\
pregnancy & 2 & 2.7 \\
Renal stone & 4 & 5.3 \\
SLE & 2 & 2.7 \\
Unknown & 11 & 14.6 \\
\hline Total & 75 & 100 \\
\hline
\end{tabular}

\section{Leptin and $\mathrm{CrCl}$}

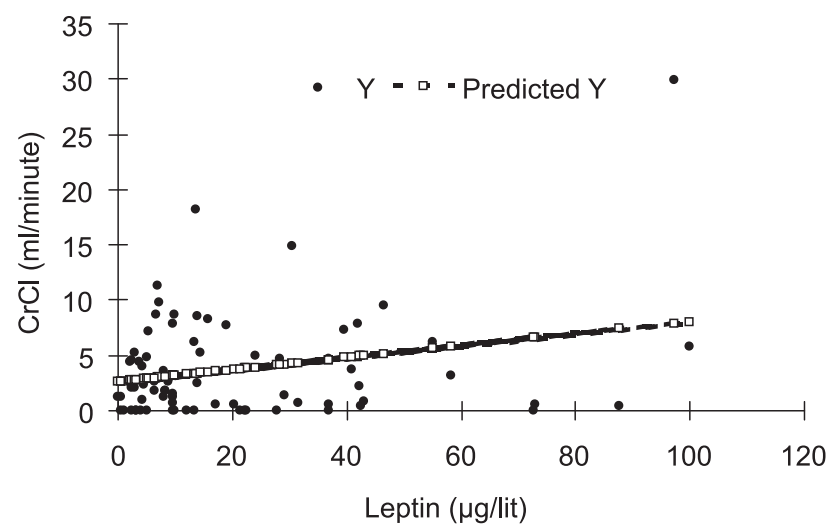

Fig. 1. Relationship between serum leptin and $\mathrm{Cr} \mathrm{Cl}$ of patients $(\mathrm{p}=0.007)$.

tients was higher than that of patients without DM (60 years vs 46 years, respectively, $\mathrm{p}=0.028)$.

Twenty three $(30 \%)$ patients had the history of hemodialysis. In $58(77 \%)$ patients, renal $\mathrm{Cr} \mathrm{Cl}$ was less than $6 \mathrm{ml} / \mathrm{min}$ and in $17(23 \%)$ patients it was equal or greater than $6 \mathrm{ml} / \mathrm{min}$. The mean serum leptin level in women and men were $33 \pm 4.44 \mu \mathrm{g} / \mathrm{l}$ and $24 \pm 3.4 \mu \mathrm{g} / \mathrm{l}$, respectively $(\mathrm{p}=0.001)$. By using univariate general linear model, a negative relationship has been shown between age and serum leptin level $(\mathrm{p}=0.028)$. There was a positive relation between the serum leptin level and the duration of chronic kidney disease $(\mathrm{p}=0.01)$. This means that patients with a more prolonged renal failure had higher serum leptin levels. Mean BMI had a rising pattern up to 70 years and began to decline thereafter (Tab. 2).

Figure 1 shows that serum leptin level had a positive correlation with renal $\mathrm{Cr} \mathrm{Cl}(\mathrm{p}=0.007)$. There was no correlation of serum leptin level with mid arm circumference, serum TG, and total and LDL cholesterol levels ( $p>0.05)$. There was a negative relationship between the serum leptin level and the duration of hemodialysis ( $\mathrm{p}=0.043)$, but there was no relation with the duration of peritoneal dialysis, albumin and total KT/V ( $>0.05)$. There

Tab. 2. Clinical and biochemical parameters of patients during the study.

\begin{tabular}{|c|c|c|c|c|c|}
\hline & Number & Minimum & Maximum & Mean & Std. Deviation \\
\hline Leptin ( $\mu \mathrm{g} /$ lit) & 75 & 0.09 & 101.00 & 22.00 & 23.00 \\
\hline Mid arm circumference $(\mathrm{cm})$ & 75 & 18.50 & 38.00 & 27.21 & 4.38 \\
\hline BMI $(\mathrm{kg} / \mathrm{m} 2)$ & 75 & 14.20 & 33.30 & 24.26 & 3.89 \\
\hline $\mathrm{TG}(\mathrm{mg} / \mathrm{dl})$ & 75 & 52.00 & 513.00 & 156.15 & 78.77 \\
\hline LDL Cholesterol (mg/dl) & 75 & 36.00 & 216.00 & 104.77 & 35.32 \\
\hline HDL Cholesterol (mg/dl) & 75 & 28.00 & 59.00 & 44.10 & 6.88 \\
\hline Total Cholesterol (mg/dl) & 75 & 109.00 & 283.00 & 179.12 & 39.72 \\
\hline $\mathrm{Cr} \mathrm{Cl}(\mathrm{ml} / \mathrm{min})$ & 75 & .0000 & 29.95 & 3.71 & 4.86 \\
\hline WEIGHT (kg) & 75 & 36.00 & 95.00 & 66.83 & 13.49 \\
\hline Duration of renal failure (months) & 75 & 0.50 & 300.00 & 43.47 & 56.03 \\
\hline Duration of peritoneal dialysis (months) & 75 & 3.00 & 70.00 & 20.16 & 13.79 \\
\hline HTN & 75 & 0.00 & 1.00 & 0.77 & 0.42 \\
\hline Duration of hemodialysis (months) & 75 & 0.00 & 72.00 & 4.27 & 12.61 \\
\hline Number of PD exchanges per day & 75 & 0.36 & 5.00 & 3.76 & 0.88 \\
\hline
\end{tabular}




\section{BMI and Leptin}

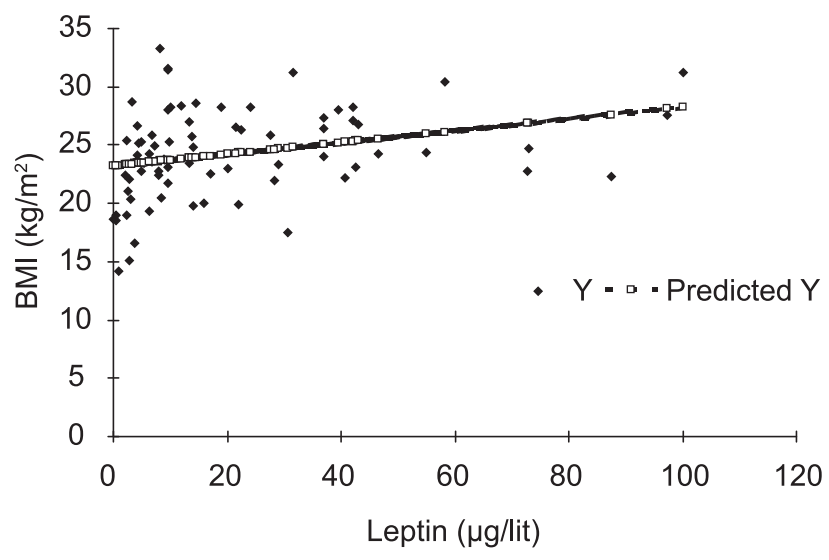

Fig. 2. Relationship between serum leptin and BMI of patients $(\mathbf{p}<0.001)$.

was a significant correlation between the serum leptin level and BMI (p<0.001) (Fig. 2).

\section{Discussion}

Some studies showed that serum leptin level is higher in female than in male population, as well as that it is higher in CAPD patients compared with those subdued to hemodialysis. Higher level of serum leptin level in CAPD patients compared to HD patients may be due to higher fat mass and serum insulin level in CAPD patients $(6,16-18)$.

Serum leptin level may have direct correlation with body fat mass, serum triglyceride, serum total and LDL cholesterol (13, 14, 16). Stenvinkel et al (19) reported higher serum leptin level in CAPD patients with weight loss but not in patients with weight gain. So leptin can be used as a malnutrition index in CAPD patients, although in some studies, leptin has been presented as an index of good nutritional status (14) and low serum leptin level as a possible predictor of higher mortality in patients with chronic kidney disease (20).

Our results showed that serum leptin level is higher in women compared to men and serum leptin level had a linear correlation with BMI, which is similar to the findings of Parry (16), Vignioble (21) and Kagen (22) but different from those of Kim (23).

These differences could be due to discrepancies in numbers of patients in these studies. In present study, serum leptin level was higher in patients with renal $\mathrm{Cr} C L \geq 6 \mathrm{ml} / \mathrm{min}$ wich may explain the higher mortality in CAPD patients with lower serum leptin level. Yilmaz et al (13) reported that in CAPD patients, serum leptin levels correlate with age and body mass index (BMI), however in Kastrainion (12) and Taskapan (24) studies they correlated with serum triglyceride and cholesterol. While in Stenvinked (19) study on 36 CAPD patients, serum leptin level had an adverse correlation with BMI, there was no correlation of serum leptin level with serum albumin, terasferin and cholesterol in Aguilera (15) study in patients with BMI $>25 \mathrm{~kg} / \mathrm{m}^{2}$. In our study, there was no cor- relation of serum leptin level with mid arm circumference, serum triglyceride, total and LDL cholesterol, and duration of peritoneal dialysis (PD). In Vignioble (21) study, serum leptin level had also no correlation with the duration of $\mathrm{PD}$. The controversy of results between different studies may be due to different sample size, sex distribution, and methods of patients' evaluation. In our study, serum leptin level had no correlation with total KT/V which is consistent with the results of Parry RG (16) and Rodríguez-Carmona (25) results. Therefore we cannot use serum leptin as an index of peritoneal dialysis adequacy.

In conclusion, this is probably the first report of a positive correlation of serum leptin level with renal $\mathrm{Cr} \mathrm{Cl}$ in $\mathrm{CAPD}$ patients. This may explain the increase in mortality in patients with lower serum leptin level.

\section{References}

1. Caro JF, Sinha MK, Kolaczynski JW, Zhang PL, Considine RV. Leptin: the tale of an obesity gene. Diabetes 1996; 45 (11): 1455-1462.

2. Meyer C, Robson D, Rackovsky N, Nadkarni V, Gerich J. Role of the kidney in human leptin metabolism. Am J Physiol 1997; 273: E 903.

3. Sharma K, Considine RV, Miochael B, Dunn SR, Weisberg LS, Kurnik BR. Plasma leptin is party cleared by the kidney and is elevated in hemodialysis patients. Kidney int 1997; 51: 1980.

4. Briley LP, Szczech IA. Leptin and renal disease. Semin Dial 2006; 19: $\mathrm{x} 54$.

5. Zbroch E, Małyszko J, Wołczyński S, Hryszko T, Myśliwiec M. Concentration of leptin in patients on hemodialysis and peritoneal dialysis. Pol Arch Med Wewn 1999; 101 (6): 503-508.

6. Dagogo-Jack S, Ovalle F, Landt M, Gearing B, Coyne DW. Hyper leptinemia in patients with end stage renal disease undergoing continuous ambulatory peritoneal dialysis. Perit Dial Int 1998; 18 (1): 34-40.

7. Fontan MP, Rodriguez-Carmona A, Cardio F, Garcia-Buela J. Hyper leptinemia in uremic patients undergoing conservative management, peritoneal dialysis, and hemodialysis : A comparative analysis. Am J kidney Dis 1999; 34 (5): 824-831.

8. Zbroch E, Małyszko J, Wołczyński S, Hryszko T, Myśliwiec M. Concentration of leptin in patients on hemodialysis and peritoneal dialysis. Pol Arch Med Wewn 1999; 101 (6): 503-508.

9. Coyne DW, Dagogo-Jack S, Klein S, Merabet E, Audrain J, Landt M. High - flux dialysis lower plasma leptin concentration in chronic dialysis patients. Am J kidney Dis 1998; 32 (6): 1031-1035.

10. Axelsson J, Qureshi AR, Heimburger O, Lindholm B, Stenvinkel P, Barany P. Body fat mass and serum leptin levels influence erythropoietin sensitivity in patients with ESRD. Am J Kidney Dis 2005; 46 (4): 628-634.

11. Zoccali C, Tripepi G, Cambareri F, Catalano F, Finocchiaro P, Cutrupi S. Adipose tissue cytokines, insulin sensitivity, inflammation, and cardiovascular outcomes in end-stage renal disease patients. J Ren Nutr 2005; 15 (1): 125-130.

12. Kastarinen H, Kesaniem YA, Ukkolu O. Leptin and lipid metabolism in chronic kidney foulure. Scand J Lab Invest 2009; 69 (3): 401-408.

13. Yilmaz A, Kayardi M, Cagasioglu S, Candon F, Nur N, Gultekin F. Relationship between serum leptin levels and body composition and markers of malnutrition in nondiabetic patients on peritoneal dialysis or hemodialysis . J Chin Med Assoc 2005; 68 (12): 566-570. 
14. Dervisoglu E, Eraldemir C, Kalender B, Kir HM, Caglayan C. Adipocytokines leptin and adiponectin, and measure of malnutrition inflammation in chronic renal failure: is there a relationship? J Ren Nutr 2008; 18 (4): 332-337.

15. Aguilera A, Bajo MA, Rebollo F, Diez JJ, Diaz C, Paiv AA et al. Leptin as a marker of nutrition and cardiovascular risk in peritoneal dialysis patients. Advperik Dial 2002; 18: 212-217.

16. Parry RG, Johnson DW, Corey DG, Hibbins M, Chang W, Purdie $\mathbf{D}$ et al. Serum leptin correlates with fat mass but not dietary energy intake in continuous ambulatory peritoneal dialysis patients. Peit Dial Int 1998; 18 (6): 569-575.

17. Arkouche W, Juillard L, Delawari E, Lasne Y, Combarnous F, Sibai-Galland R et al. Peritoneal clearance of leptin in continuous ambulatory peritoneal dialysis. Am J Kidney Dis 1999; 34 (5): 947-950.

18. Howard L, Lord GM, Clutterbuck EJ, Ghatei MA, Pusey CD, Bloom SR. Plasma immunoreactive leptin concentration in end-stage renal disease. Clin Sci (Lond) 1997; 93 (2): 119-126.

19. Stenvinkel P, Lindholm B, Lonnqvist F, Katzarki K, Heimburger O. Increased in serum lepitn levels during peritoneal dialysis are associated with inflammation and a decrease in lean body mass. J Am Soc Nephrol 2000; 11 (7): 1303-1309.
20. Scholze A, Rattensperger D, Zidek W, Tepel M. Low serum leptin predicts mortality in patients with chronic kidney disease stage 5 . Obesity (Silver Spring) 2007; 15( 6): 1617-1622.

21. Vignioble M, Brichard S, Jadoual M, Goffin E. Serum leptin concentration in peritoneal dialysis patients: determinants, longitidunal evaluation and circadian rhythm. Acta Clin Belg 2001; 56 (3): 173-179.

22. Kagan A, Haran N, Leschinsky L, Schuali N, Rapoport J. Leptin in CAPD patients: Serum concentrations and peritoneal loss. Nephrol Dial Transplant 1999; 14 (2): 400-405.

23. Kim DJ, Oh DJ, Kim B, Lim YH, Kang WH, Lee SK et al. The effect of continuous ambulatory peritoneal dialysis on change in serum leptin. Perit Dial Int 1999; 19 (Suppl 2): 5172-5175.

24. Taskapan MC, Taskapan H, Sabin I, Keskin L, Atmaca H, Ozyalin F. Serum leptin, resistin, and lipid levels in patients with end stage renal failure with regard to dialysis modality. Ren Fail 2007; 29 (2): 147-154.

25. Rodríguez-Carmona A, Pérez Fontán M, Sordid F, García Falcón T, García-Buela J. Hyperleptinemia is not correlated with markers of protein malnutrition in chronic renal failure. A cross-sectional study in predialysis, peritoneal dialysis and hemodialysis patients. Nephron 2000; 86 (3): 274-280. 